\title{
Analisis Kemampuan Berhitung Siswa Kelas III SD Negeri Kecamatan Ulaweng Kabupaten Bone
}

\author{
Syamsuddin S. ${ }^{1}$, Muhammad Idris Jafar ${ }^{2}$, Rahmawati Patta \\ 1,2,3Program Studi PGSD Fakultas Ilmu Pendidikan UNM \\ ${ }^{1}$ syamsuddin.s@unm.ac.id \\ ${ }^{2}$ m.idris.jafar@unm.ac.id \\ 3rahmawati.patta@unm.ac.id
}

\begin{abstract}
ABSTRAK
Tujuan yang ingin dicapai dalam penelitian adalah untuk memperoleh gambaran tingkat kemampuan siswa kelas III SD Kecamatan Ulaweng Kabupaten Bone.Penelitian ini termasuk penelitian deskriptif kuantitatif yang bervariabel tunggal, yaitu kemampuan berhitung siswa kelas III SD. Populasinya adalaah seluruh siswa kelas III SD Negeri Kecamatan Ulaweng Kabupaten Bone. Sampel sekolah ditarik secara area random sampling setiap gugus kepengawasan UPTD Kecamatan Ulaweng. Karena ada empat gugus sehingga ada empat sekolah sebagai sampel sekolah dan siswa kelas III dari sekolah tersebut sekaligus menjadi subjek penelitian. Instrumen pengumpulan data digunan tes. Data hasil tes dianalisis dengan teknik analisis statistik deskriptif berupa distribusi frekuensi, rata-rata hitung, simpangan baku, dan persentase. Berdasarkan analisis data disimpulkan bahwa tingkat kemampuan berhitung siswa kelas III SD Negeri Kecamatan Ulaweng Kabupaten Bone berada pada kategori rendah. Rendahnya hasil belajar matematika siswa kelas III SD, tentunya dapat direkomendasikan kepada semua pihak yang punya kepentingan dalam dunia pendidikan agar dapat lebih berupaya meningkatkan proses pembelajar matematika di sekolah dasar.
\end{abstract}

Kata kunci: Kemampuan Berhitung, Siswa SD

\section{PENDAHULUAN}

Dalam rangka meningkatkan mutu pendidikan dan usaha menyiapkan sumber daya manusia yang berkualitas sesuai dengan standar kompetensi yang ditetapkan secara nasional, perlu dilakukan penilaian hasil belajar secara sistematis dan berkelanjutan. Kaitannya dengan mutu pendidikan pada jenjang pendidikan sekolah dasar (SD), ada tiga kemampuan dasar yang mesti dikuasai oleh setiap siswa, yaitu kemampuan membaca, kemampuan menulis, dan kemampuan berhitung. Ketiga kemampuan ini merupakan dasar untuk mempelajari mata-mata pelajaran lain dan digunakan dalam kehidupan sehari-hari. Kemampuan dasar ini merupakan kemampuan minimal yang harus dimiliki oleh setiap siswa yang belajar setingkat dengan SD. Namun, hingga kini masih ada keluhan dari berbagai pihak tentang mutu lulusan berbagai jenis pendidikan.

Di antara mata pelajaran yang selalu menjadi perhatian dari berbagai kalangan orangtua dan masyarakat adalah berhitung (matematika). Hal ini dapat dipahami karena matematika mempunyai proporsi waktu yang besar dibandingkan dengan pelajaran lain. Juga banyak persoalan keseharian anak yang perlu diselesaikan melalui perhitungan, seperti menghiutng banyaknya benda, banyaknya uang yang dimiliki, dapat menghitung banyaknya belanja setiap hati, menentukan waktu dan lainlain.

Pelajaran berhitung di SD identik dengan pelajaran matematika. Hal ini disebabkan karena matematika di SD umumnya berhubungan dengan perhitungan-perhitungan dengan menggunakan angka-angka sehingga matematika berubah namanya menjadi berhitung. Matematika adalah suatu mata pelajaran yang tersusun secara beraturan logis dari yang paling sederhana hingga yang paling sulit. Hal ini sesuai dengan pernyataan Hudoyo (1990: 4) yang menyatakan bahwa:

Pada hakekatnya matematika itu berkenaan dengan ide-ide, struktur, dan hubungan-hubungannya diatur menurut urutan logis. Ide-ide dalam struktur ini 
merupakan konsep-konsep yang abstrak yang tersusun secara hirarkis dan penalarannya secara deduktif.

Pendapat tersebut di atas dapat diartikan bahwa dalam belajar matematika, seorang siswa akan lebih mudah mempelajari suatu materi matematika apabila siswa tersebut telah memahami materi prasyarat dari bahan yang sedang dipelajari. Hal ini perlu karena sifat kehirarkian materi matematika yang sangat kuat. Kelemahan penguasaan materi prasyarat akan menyulitkan siswa dalam mempelajari materi selanjutnya.

Kehirarkian materi pelajaran matematika (berhitung) dapat ditunjukkan misalnya dalam perkalian. Untuk mampu melakukan perkalian siswa harus mampu melakukan penjumlahan, karena perkalian adalah tidak lain dari penjumlahan berulang. Selanjutnya untuk mampu melakukan penjumlahan, maka terlebih dahulu siswa harus mampu mengelompokkan benda-benda kongkrit, membilang, dan mampu menuliskan lambang-lambang bilangan. Demikian seterusnya kemampuan penguasaan materi tersebut saling terkait, baik sesudah perkalian maupun sebelum penjumlahan.

Belajar merupakan transformasi masukan berupa stimuli menjadi keluaran. Hasil belajar selalu dapat diobjektifkan sebagai perubahan tingkah laku yang dapat diamati dari penampilan orang yang belajar itu. Penampilan biasanya beraneka ragam, mulai dari yang sederhana sampai yang kompleks seperti pemecahan masalah. Namun demikian, keadaan yang mendasarinya mempunyai ciri-ciri yang sama. Keadaan yang sifatnya tetap itu disebut kemampuan.

Banyak faktor yang dapat menentukan keberhasilan dalam mempelajari matematika. Keberhasilan tersebut tidak hanya dipengaruhi oleh faktor luar seperti guru, metode mengajar guru, dan kelengkapan fasilitas belajar, tetapi juga dipengaruhi oleh faktor dari dalam diri siswa. Faktor dari dalam diri siswa seperti minat, kesadaran, kemauan, dan juga bergantung kepada kemampuannya terhadap pelajaran matematika (Sameto, 1987: 9). Untuk beberapa bagian atau cabang matematika tertentu juga diperlukan keterampilan intelektual, misalnya keterampilan menghitung, keterampilan mengintegralkan, keterampilan mengubah rumus dari satu bentuk ke bentuk yang lain, keterampilan menerjemahkan kalimat verbal (cerita) ke dalam kalimat (model) matematika, dan lain-lain.

Pelajaran berhitung harus sesuai dengan tingkat perkembangan siswa. Menurut Piaget dalam Hudoyo (1990: 35), bahwa anak yang berumur 6-12 tahun masihdalam taraf berpikir operasi kongkrit. Umur tersebut merupakan usia yang umum pada siswa-siswa SD di Indonesia. Karena matematika merupakan hal yang abstrak sedangkan tingkat berpikir siswa SD masih berada pada taraf berpikir operasi kongkrit, maka perlu ada cara atau media untuk menjembatani kedua hal tersebut di atas, yakni penggunaan alat peraga. Oleh karena itu dalam melakukan kegiatan pembelajaran berhitung di SD seharusnya guru menggunakan alat peraga.

Secara umum tujuan pembelajaran matematika di sekolah dasar, yaitu agar siswa mampu dan terampil menggunakan matematika dalam kehidupan sehari-hari. Depdiknas (Susanto, 2016) mengungkapkan bahwa kompetensi atau kemampuan umum pembelajaran matematika di sekolah dasar adalah:

(1) Melakukan operasi hitung penjumlahan, pengurangan

perkalian, pembagian, beserta operasi campuran, termasuk yang melibstksn pecahan; (2) menentukan sifat dan unsur sebagai bangun datar dan bangun ruang sederhana, termsuk penggunaan sudut, keliling, luas dan volume; (3) menentukan sifat simetri, kebangunan, dan sistem koordinat; (4) menggunakan pengukuran satuan, kesetaraan antar satuan, dan penaksiran pengukuran; (5) menentukan dan menafsirkan data sederhana, seperti ukuran tertinggi, terendah, rata-rata, modus, mengumpul kan data dan menyajikannya; (6) memecahkan masalah, melakukan penalaran, dan mengkomunikasikan gagasan secara matematika.

Dalam Kurikulum Tingkat Satuan Pendidikan (KTSP, 2006: 417) merumuskan, agar peserta didik memiliki kemampuan sebagai berikut:

(1) memahami konsep matematika, menjelaskan keterkaitan antar konsep dan mengaplikasikan konsep atau algoritma secara luwes, akurat, efisien, dan tepat dalam memecahkan masalah; (2) menggunakan penalaran pada pola dan sifat, 
melakukan menipulasi matematika daan membuat generalisasi, menyusun bukti, atau menjelaskan gagasan dan pernyataan matemtika; (3) memecah kan masalah yang meliputi kemampuan memahami masalah, merancang model matematika, menyelesai kan model dan menafsirkan solusi yang diperoleh; (4) mengkomunikasi gagasan dengan simbol, tabel, diagram, atau media lain untuk memperjelas keadaan atau masalah; (5) memiliki sikap menghargai kegunaan matematika dalam kehidupan, yaitu memiliki rasa ingin tahu, perhatian, dan minat dalam mempelajari matematika, serta sikap ulet dan percaa diri dalam pemecahan masalah.

Materi dasar dalam berhitung yang merupakan bagian dari pelajaran matematika merupakan alat yang penting bagi seorang siswa untuk menguasai pelajaran lain, misalnya IPS, bahasa Indonesia dan IPA, disamping juga merupakan kesiapan untuk menghadapi materimateri pelajaran matematika pada tingkatan kelas dan jenjang sekolah berikutnya. Pada Buku Depdiknas (2002: 7-8), materi-materi standar kompetensi (kemampuan dasar) berhitung pada kelas III SD meliputi tentang bilangan, yang meliputi: 1) bilangan dan lambangnya, 2) nilai tempat, 3) penjumlahan dengan hasil sampai dengan 5.000,4) pengurangan, 5) penjumlahan dan pengurangan, 6) perkalian, 7) pembagian, 8) perkalian dan pembagian, 9) membandingkan dua bilangan, 10) mengenal dan menentukan waktu, dan 12) pecahan. Dari ke-12 topik materi tersebut dapat dikelompokkan lagi menjadi tiga kelompok, yaitu: (1) bilangan dan lambang bilangan, (2) operasi hitung dasar bilangan: (penjumlahan, pengurangan, pembagian, perkalian, dan campuran), mengurutkan bilangan, dan (3) pengukuran.

Kemampuan siswa untuk menguasai semua materi tersebut di atas merupakan kemampuan dasar yang perlu dimiliki siswa kelas rendah (Kelas III) untuk dapat menerima materi-materi matematika (berhitung) lanjutan di kelas tinggi (kelas IV-VI). Di samping itu, dapat juga berfungsi sebagai dasar kemampuan berkomunikasi dengan menggunakan bilangan dan simbol-simbol serta ketajaman penalaran yang dapat membantu memperjelas dan menyelesaikan permasalahan dalam kehidupan sehari-hari.
Berdasarkan hal tersebut di atas, maka penulis tertarik untuk menelusuri kemampuan berhitung siswa kelas III SD Kecamatan Ulaweng Kabupaten Bone. Dari hasil penelitian ini diharapkan minimal akan dapat menjadi bahan informasi bagi guru, kepala sekolah/pengawas, siswa maupun bagi pengambil kebijakan, baik di tingat kecamatan maupun di tingkat kabupaten dalam upaya peningkatan proses dan hasil pembelajaran berhitung (matematika) di Sekolah Dasar.

\section{METODE PENELITIAN}

Pendekatan yang digunakan adalah pendekatan deskriptif-kuantitatif. Populasinya adalah seluruh siswa kelas III SD di Kecamataan Ulaweng Kabupaten Bone tahun pelajaran yang sedang berjalan, dan sampel dapat diambil secara area random sampling, dimana setiap wilayah kepengawasaan sekolah (gugus) dipilih secara acak satu sekolah sekolah (SD) yang mewakili gugus tersebut. Seluruh siswa kelas III dari sekolah sampel tersebut sekaligus menjadi sampel dalam penelitian ini. Data yang diperoleh akan dianalisis secara statistik deskriptif dengan teknik distribusi frekuensi, grafik/diagram, ratarata hitung, dan persentase.

\section{HASIL \& PEMBAHASAN}

Kemampuan berhitung yang akan dianalisis mencakup dua hal, yaitu 1) analisis kemampuan berhitung dari masing-masing sekolah sampel setiap gugus; dan 2) analisis kemampuan siswa dari tiga aspek berhitung yaitu: (a) penguasaan bilangan dan lambang bilangan, (b) penguasaan operasi hitung bilangan, dan c) penguasaan tentang pengukuran (pengukuran panjang dan pengukuran waktu). Hasil yang diperoleh dapat dirangkum dalam tabel 1 berikut. 
Tabel 1 Rangkuman Persentase Rata-rata Tingkat Kemampuan Berhitung.

\begin{tabular}{|c|c|c|c|c|}
\hline $\begin{array}{c}\text { Aspek } \\
\text { Berhitung }\end{array}$ & Nama Sekolah & $\begin{array}{c}\text { Tinggi } \\
(\%)\end{array}$ & $\begin{array}{c}\text { Sedang } \\
(\%)\end{array}$ & $\begin{array}{c}\text { Rendah } \\
(\%)\end{array}$ \\
\hline \multirow{5}{*}{$\begin{array}{c}\text { Bilangan dan } \\
\text { Lambang } \\
\text { Bilangan }\end{array}$} & SD Inp.12/79 P.Rukka & 40,00 & 40,00 & 20,00 \\
\hline & SDN 132 Galung & 31,25 & 31,25 & 37,50 \\
\hline & SDN 137 Canisirenreng & 28,58 & 35,71 & 35,71 \\
\hline & SDN 141 L.Ajangale & 33,33 & 44,44 & 22,22 \\
\hline & Rata-rata & 33,29 & 37,85 & 28,86 \\
\hline \multirow{5}{*}{$\begin{array}{l}\text { Operasi } \\
\text { Hitung } \\
\text { Bilangan }\end{array}$} & SD Inp.12/79 P.Rukka & 30,00 & 35,00 & 35,00 \\
\hline & SDN 132 Galung & 37,50 & 25,00 & 37,50 \\
\hline & SDN 137 Canisirenreng & 21,43 & 50,00 & 28,57 \\
\hline & SDN 141 L.Ajangale & 33,33 & 44,44 & 22,22 \\
\hline & Rata-rata & 30,57 & 38,61 & 30,82 \\
\hline \multirow{5}{*}{ Pengukuran } & SD Inp.12/79 P.Rukka & 25,00 & 35,00 & 40,00 \\
\hline & SDN 132 Galung & 45,00 & 25,00 & 31,25 \\
\hline & SDN 137 Canisirenreng & 28,58 & 35,71 & 35,71 \\
\hline & SDN 141 L.Ajangale & 44,44 & 11,12 & 44,44 \\
\hline & Rata-rata & 35,76 & 26,71 & 37,85 \\
\hline \multicolumn{2}{|c|}{ Rata-rata Keseluruhan } & 33,21 & 34,39 & 32,51 \\
\hline
\end{tabular}

Dari tabel 1 di atas, nampak bahwa persentase rata-rata tingkat kemampuan berhitung siswa kelas III yang berada pada kategori tinggi ada sekitar 33,21\%, kategori sedang ada sekitar 34,39\%, dan kategori rendah ada sekitar $32,51 \%$. Dari hasil analisis statistik deskriptif nilai kemampuan berhitung siswa kelas III di atas, memberikan gambaran bahwa skor rata-rata siswa dari masing- masing sekolah sampel berada pada ketegori rendah.

Selain analisis berdasarkan taksiran rata-rata di atas, dapat pula dideskripsikan berdasarkan analisis rata-rata dan simpangan baku. Dari hasil tes yang diperoleh dapat dipaparkan rekapitulasi hasil analisis rata-rata dan simpangan seperti pada tabel 2 berikut.

Tabel 2 Rekapitulasi rata-rata dan simpangan baku persekolah sampel setiap gugus.

\begin{tabular}{|c|l|c|c|c|}
\hline No. & \multicolumn{1}{|c|}{ SD/Gugus } & Rata-rata & $\begin{array}{c}\text { Simpangan } \\
\text { Baku }\end{array}$ & \\
\hline 1 & SD Inp.12/79 Pallawarukka & 40,85 & 12,88 & \\
\hline 2 & SD Negeri 132 Galung & 26,25 & 10,33 & \\
\hline 3 & SD Negeri 137 Canisirenreng & 40,5 & 14,33 & \\
\hline 4 & SD Negeri 141 L. Ajangale & 46,78 & 17,78 & \\
\hline \multicolumn{2}{|c|}{ Rata-rata } & 38,6 & 13,83 & Rendah*) \\
\hline
\end{tabular}

*) Standar Kriteria Penskoran

Rendahnya kemampuan berhitung siswa kelas III SD Negeri Kacamatan Ulaweng Kabupaten Bone seperti yang dipaparkan pada tabel 2 di atas, tidak terlepas dari dua faktor penyebabnya, yaitu faktor dari dalam diri siswa sendiri dan faktor dari luar diri siswa. Faktor dari dalam diri siswa, antara lain motivasi belajar, minat belajar, kebiasaan belajar (di rumah maupun di sekolah), khususnya dalam pelajaran matematika. Faktor dari luar diri siswa, disebabkan antara lain dari guru kelas, dari lingkungan sekolah dan keluarga. Penyebab dari guru kelas, antara lain cara/metode/teknik mengajar guru, khususnya dalam matematika kurang memanfaatkan media/alat peraga dalam menanamkan konsepkonsep matematika, dimana guru-guru kelas yang ada masih kebanyakan guru honorer yang berkualifikasi S-1 bidang studi (Bahasa Indonesia, PKN) dari STKIP Muhammadiyah Bone. Dari lingkungan sekolah dan keluarga, dimana anak-anak yang tinggal di pedesaan sangat dipengaruhi kondisi musiman/cuaca, seperti musin panen (padi, jagung, kedele) kadang anak membantu orang tua di ladang/sawah, musim hujan turun di sawah menanam padi, dan sebagainya. 


\section{KESIMPULAN \& SARAN}

Berdasarkan hasil analisis data dan pembahasan, maka dapat ditarik kesimpulan sebagai berikut:

1. Gambaran kemampuan berhitung siswa kelas III SD Inp. 12/79 Pallawarukka dari jumlah siswa 20 orang, nilai tertingg 65 , nilai terendah 10 , rata-rata 40,85 , dan standar deviasi 12,88, dengan tingkat kemampuan berhitung siswa $25 \%$ dalam kategori tinggi, 55\% dalam kategori sedang, dan $20 \%$ dalam kategori rendah. Sehingga tingkat kemampuan berhitung siswa cenderung berada dalam kategori rendah

2. Gambaran kemampuan berhitung siswa kelas III SD Negeri 132 Galung dari jumlah siswa 16 orang, nilai tertinggi 48 , nilai terendah 13 , rata-rata 26,25 , dan standar deviasi 10,33, dengan tingkat kemampuan berhitung siswa $31,25 \%$ dalam kategori tinggi, 31,25\% dalam kategori sedang, dan $37,75 \%$ dalam kategori rendah. Sehingga tingkat kemampuan berhitung siswa cenderung berada dalam kategori sangat rendah.

3. Gambaran kemampuan berhitung siswa kelas III SD Negeri 137 Canisirenreng dari jumlah siswa 14 orang, nilai tertingg 68 , nilai terendah 18 , rata-rata 40,5 , dan standar deviasi 14,33, dengan tingkat kemampuan berhitung siswa $21,43 \%$ dalam kategori tinggi, $50 \%$ dalam kategori sedang, dan $28,57 \%$ dalam kategori rendah. Sehingga tingkat kemampuan berhitung siswa cenderung berada dalam kategori rendah.

4. Gambaran kemampuan berhitung siswa kelas III SD Negeri 141 Lilina Ajangale dari jumlah siswa 9 orang, nilai tertingg 73, nilai terendah 10 , rata-rata 46,78 , dan standar deviasi 17,78, dengan tingkat kemampuan berhitung siswa $25 \%$ dalam kategori tinggi, 55\% dalam kategori sedang, dan $20 \%$ dalam kategori rendah. Sehingga tingkat kemampuan berhitung siswa cenderung berada dalam kategori rendah.

Secara keseluruhan disimpulkan bahwa kemampuan berhitung siswa kelas III SD Negeri Kecamatan Ulaweng berada dalam kategori rendah. Rendahnya hasil belajar matematika (berhitung) siswa kelas III SD, tentunya dapat direkomendasikan kepada semua pihak yang punya kepentingan dalam dunia pendidikan agar dapat lebih berupaya meningkatkan proses pembelajaran matematika di sekolah dasar.

DAFTAR PUSTAKA

Arikunto, Suharsimi. 1992. Prosedur penelitian: Suatu Pendekatan Praktik. Jakarta : Rineka Cipta.

Depdikbud. 1993. Kurikulum Pendidikan Dasar: Landasan, Program, dan Pengembangan. Jakarta: Depdikbud.

Depdiknas. 2002. Pedoman Pelaksanaan Tes Kemampuan Dasar bagi Siswa Kelas 3 SD, SDLB, SLB Tingkat Dasar dan MI. Jakarta : Depdiknas.

2006. Kurikulum Tingkat Satuan Pendidikan (KTSP) Mata Pelajaran Matematika/Berhitung. Jakarta: Depdiknas.

Furchan, Arief. 1982. Pengantar Penelitian dalam Pendidikan. Surabaya: Usaha Nasional.

Gulo, Dali. 1982. Kamus Psikologi. Bandung: Tonus.

Hudoyo, Herman. 1990. Strategi Belajar Mengajar Matematika. Jakarta: Depdikbud.

Jacob, Teuku. 16 Juli 1996. Menurunnya Mutu Pendidikan Bukan Soal Baru. Kompas. Hlm. 4.

Jufri, H., dkk. 2017. Panduan Penelitian $P N B P$. Lembaga Penelitian Universitas Negeri Makassar. Makassar: Badan Penerbit UNM.

Samekto, S. 1987. Hubungan Antara Kemampuan Penalaran dan Prestasi Belajar Matematika Siswa SMP. Jurnal Kependidikan, IKIP Yogyakarta. No. 1 Tahun ke 18

Sugiono, 2011. Metode Penelitian Kombinasi (Mixed Methods). Bandung: Alfabeta.

Sukarti. 1986. Suatu Studi Mengenai Prediksi Terhadap Prestasi Belajar di STM Yogyakarta. Disertasi. Program Pasca Sarjana Universitas Gajah Mada.

Sukirin. 1975. Tingkat Kesiapan sebagai Titik Permulaan Perkembangan Baru. Pidato. Disampaikan pada Pengukuhan Rektor Kepala Psikologi Perkembangan pada FIP IKIP Yogyakarta.

Sumarna dan Asep, S. 2002. Gemar Berhitung Matematika 3A. Bandung: Garafindo Media Pratama.

Suprapto, B. 1980. Mutu Pendidikan Menengah Umum. Analisis Pendidikan, Tahun I No. 2: 109-117. 